\title{
CARING FOR "PARENTLESS" CHILDREN: AN EXPLORATION OF WORK STRESSORS AND RESOURCES AS EXPERIENCED BY CAREGIVERS IN CHILDREN'S HOMES IN GHANA
}

\author{
Ernest Darkwah, Maxwell Asumeng, and Marguerite Daniel
}

\begin{abstract}
The experience of stress by workers in any work environment has negative impacts on employee health and productivity. However, work resources are known to have possible neutralizing impacts on the negative effects of stress depending on the availability of those resources and the extent to which employees are able to identify and utilize them. This study explores this stress-resource relationship and its implications in a work context where the lives of vulnerable children depend on the wellbeing and productivity of their employed caregivers. Qualitative exploratory techniques were used to investigate the sources and nature of stressors experienced by caregivers and the extent to which caregivers identify and utilize resources available in that work environment. Participants comprised 41 caregivers from 2 children's homes in Ghana. It emerged that aspects of the work environment that were identified as stressors also tended to be identified as resources for caregivers. These included the children, the work environment, institution-community relations, and relationships between caregivers and their own families. Caregiver faith and intrinsic motivation stood out as the most frequently reported of the resources upon which caregivers drew to cope with their jobs.
\end{abstract}

Keywords: children's homes, caregivers, stressors, resources, parentless children, workplace stress

Ernest Darkwah (the corresponding author) is a $\mathrm{PhD}$ candidate in the Department of Health Promotion and Development, University of Bergen, P.O. Box 7807, 5020 Bergen, Norway. Email: ernest.darkwah@student.uib.no

Maxwell Asumeng is a Senior Lecturer and Occupational Psychologist in the Department of Psychology, University of Ghana, Legon-Accra, Ghana. Email: masumeng@ug.edu.gh

Marguerite Daniel is associate professor in the Department of Health Promotion and Development, University of Bergen, Bergen, Norway. Email: Marguerite.Daniel@ uib.no 
In Ghana, children's homes (CHs) are residential institutions that provide care for children without parental care (CWPC). Described as a last-resort alternative care measure for such children (Department of Social Welfare, 2015; Manful, Takyi, \& Gambra, 2015), CHs typically take CWPC into residential care and employ caregivers to assume parental care. Caregivers' responsibilities include feeding and clothing the children, as well as providing emotional, social, and psychological support (Bettman, Mortensen, \& Akuoko, 2015; SOS Children's Villages International, 2010). The caregiver's ability to carry out socioemotional and psychological support responsibilities is crucial for the child's cognitive and physical development (Groark, Muhamedrahimov, Palmov, Nikiforova, \& McCall, 2005; Johnson et al., 2010; Richter, 2004). In the Ghanaian context, caregivers may face many difficulties in carrying out these responsibilities, including a high child-caregiver ratio, poor institutional facilities, and poor work resources (Castillo, Sarver, Bettmann, Mortensen, \& Akuoko, 2012). With some of the children in residence having been previously exposed to trauma, including abuse, maltreatment, and death of parents, caregivers face a stressful job in "parenting” these "parentless” children.

When child care workers are under stress, there can be negative impacts for both the workers and the children. The National Institute for Occupational Safety and Health (NIOSH; 1999a, 1999b) defines workplace stress as the harmful physical and emotional responses that occur when the requirements of a job do not match the capabilities, resources, or needs of the worker. The International Labour Organization (ILO; 2012) notes that stress in the workplace has the potential to inflict negative consequences on employee health and wellbeing, reducing productivity and thus impeding organizational success. In CHs, the work outcomes and productivity of employee caregivers and their institutions can have direct consequences for the health and welfare of the children in their care.

\section{The Work Stress-Resource Interface and the Institutional Care Work Environment}

Work stress has been recognized for some time as the most common risk factor in today's workplaces (Chenoweth, 1998), with a wide range of negative physiological and psychosocial consequences, such as cardiovascular disease, loss of concentration, burnout, emotional exhaustion, aggression, and incivility (Gacovic \& Tetrick, 2003; Michie, 2002; Spector, Fox, \& Domagalski, 2006; Torkelson, Holm, Bäckström, \& Schad, 2016). In the human care services, reported negative effects of work stress include caregiver ambivalence, depression, anxiety, agitation, and caregiver-client tensions (Groark et al., 2005; Wieclaw, Agerbo, Mortensen, \& Bonde, 2006;). Such consequences could be particularly worrying in CWPC care institutions since the CWPC care work environment is one in which employee work outcomes have direct consequences for the children.

However, researchers have revealed that the availability of resources in work environments has the potential to reduce the harmful physiological and psychosocial effects of stressors on workers (see Bakker \& Demerouti, 2007; Huhtala, Feldt, Lämsä, Mauno, \& Kinnunen, 2011; Hyvönen, Feldt, Salmela-Aro, Kinnunen, \& Mäkikangas, 2009). Resources are physical, psychological, social, or organizational aspects of the job that reduce job demands 
and associated physiological and psychological costs and that are functional in achieving work goals and stimulating personal growth, learning, and development (Schaufeli \& Bakker, 2004).

The documented relationship between stressors and resources is confirmed by the health promotion theory of salutogenesis, which refers to resources as a range of factors (biological or personal, material, psychosocial, etc.) that make it possible for individuals to view their lives as consistent, structured, and understandable, and therefore to better manage tension and stress (Antonovsky, 1993). By focusing on health rather than disease, the theory takes a positive approach to promoting health (Eriksson \& Lindström, 2008; Hanson, 2007). It builds on popular work stress-resource theories such as the Job Demand-Resources Model (Bakker \& Demerouti, 2007; Demerouti, Bakker, Nachreiner, \& Schaufeli, 2001). It argues that the availability of resources in any environment, and the ability of individuals to identify and utilize those resources, are key to empowering them to comprehend, manage, and make meaning of their situations - to develop a sense of coherence (SOC). The SOC is a central concept within the theory of salutogenesis, which argues that the extent of the SOC people have in a given situation determines the degree to which their present stress will affect their future health trajectories. Scholars who utilize the salutogenesis theory regard the SOC as having three key components: comprehensibility, manageability, and meaningfulness. Comprehensibility is the extent to which one believes that the world is understandable and that a sense of order can be sustained even in unknown circumstances; manageability is the extent to which one feels that one has adequate resources to deal with life's stressors; and meaningfulness is the extent to which one believes that things make sense and that what people do in life is worth the energy they invest in it (Antonovsky, 1993). Together, these three components influence the extent to which people manage to remain healthy despite stress in their environments. Many workplace interventions focus on a disease prevention approach by trying to remove stressors at work, whereas a health promotion (salutogenic) approach to addressing work stress would strive to foster the growth of each employee's SOC, promoting health despite the stress.

The work stress-resource relationship and the implications of this relationship for workers in diverse work environments have been well researched (Bakker \& Demerouti, 2007; Brauchli, Jenny, Füllemann, \& Bauer, 2015; de Jong, Le Blanc, Peeters, \& Noordam, 2008; Schaufeli \& Taris, 2014). A considerable amount of such research comes from the care industry, but the particular work setting of residential institutions that provide care for CPWC is conspicuously absent from this body of research. Instead, research in the institutional CWPC care environment has largely focused on the children and the various ways in which their lives and development are affected by that environment (see The St. Petersburg-USA Orphanage Research Team, 2008; Freidus, 2010; Groark et al., 2005; Johnson et al., 2010; Perry, Sigal, Boucher, \& Paré, 2006; Trout, Hagaman, Casey, Reid, \& Epstein, 2008; Yendork \& Somhlaba, 2015). This research has often been critical of caregivers, sometimes resulting in negative public rhetoric against them (see Anas, 2010, 2015). There is general agreement that little is known and therefore little is being done about the work situations of institutional CWPC caregivers (Castillo et al., 2012; Pretorious, 2013). 
The dearth of research into how caregivers in CWPC care institutions experience their work constitutes a significant gap in the workplace health promotion and occupational health literature. Inspired by the salutogenesis theoretical approach, this study explores the stressresource experiences of caregivers in CWPC care institutions in Ghana, and the implications of these experiences for their work and wellbeing. We interpret caregiver accounts of experiences at work in terms of the SOC elements of comprehensibility, manageability, and meaningfulness.

\section{Objectives}

The objectives of this study were to:

1. Explore the stressors in CWPC caregiving work as experienced by caregivers in CHs in Ghana.

2. Investigate the resources available, as identified and utilized by caregivers doing CWPC care work in CHs in Ghana.

\section{Methodology}

\section{Approach and Study Design}

Because this study explores subjective caregiver lived experiences of care within the context of CHs, the qualitative research approach with a phenomenological (descriptive and interpretative) design was used. Compared to other methods, this approach and design gave us a better opportunity to probe the whys and hows of caregiver experiences of the phenomenon of care (Cresswell, 2009; Green \& Thorogood, 2014).

\section{Participants and Setting}

Data were collected from 41 caregivers in two CHs located in the Greater Accra and Eastern regions of Ghana, West Africa. One of the participating institutions was owned and run by the government while the other was owned and run by a private, externally funded organization. Participants were mainly core caregivers involved in providing day-to-day quasiparental care for the children. Within their organizations, they were often called "mothers", "fathers", and "aunties". Other institutional staff such as managers, social workers, nurses, former institutional children, and educational workers also participated in the study. Table 1 presents details of participant demographics. 
Table 1 Details of Participant Demographics

\begin{tabular}{|c|c|c|}
\hline Item & Category & Number \\
\hline \multirow[t]{2}{*}{ Sex } & Male & 8 \\
\hline & Female & 33 \\
\hline \multirow[t]{4}{*}{ Age Range } & $25-35$ & 5 \\
\hline & $36-45$ & 5 \\
\hline & $46-55$ & 22 \\
\hline & $56-58$ & 9 \\
\hline \multirow[t]{4}{*}{ Education } & Post-graduate & 1 \\
\hline & Bachelor level & 3 \\
\hline & Professional/Vocational/Diploma & 11 \\
\hline & Middle school & 26 \\
\hline \multirow[t]{8}{*}{ Work Role } & Manager/Director & 2 \\
\hline & Mother & 22 \\
\hline & Father & 1 \\
\hline & Assistant mother/Auntie & 7 \\
\hline & Former institutional child/Volunteer & 3 \\
\hline & Resident nurse & 2 \\
\hline & Teacher & 2 \\
\hline & Social worker & 2 \\
\hline \multirow[t]{4}{*}{ Length of Service } & $0-10$ & 6 \\
\hline & $11-20$ & 14 \\
\hline & $21-30$ & 13 \\
\hline & $31-40$ & 8 \\
\hline \multirow[t]{4}{*}{ Marital status } & Single & 8 \\
\hline & Married & 14 \\
\hline & Divorced & 12 \\
\hline & Widowed & 7 \\
\hline
\end{tabular}

\section{Data Procedures}

Data were collected in two phases. The first phase took place from June to August 2015 and the second in March and April 2016. Data collection techniques involved participant observations, focus group discussions, and in-depth interviews.

\section{Participant Observation}

The participant observation technique was used in order to observe caregivers in their natural work environments and record first-hand information and reflections regarding caregiver handling of various work situations in our field notes and journals respectively. The strategy also offered us the opportunity to interact informally with caregivers at work; this enabled us to develop a rapport with some of the workers that made them comfortable enough to share their work experiences with us. The observing author stayed at each institution for four weeks helping children with homework and helping clean the compounds while interacting with caregivers as they went about their daily work activities. During data analysis, consistency and trustworthiness were improved by triangulation of the total data set as we sought corroboration between these field notes and the data gathered from focus group discussions and in-depth interviews. 


\section{Focus Group Discussions}

The participant observations were followed by focus group discussions in each institution. Discussants were recruited through friendly interactions during the participant observations. There were 16 participants in total, all of them mothers and aunties in their respective institutions. The mothers were women in charge of home units and the aunties were assistants to mothers. Sample themes for discussion included: "What are the work roles of a caregiver in this institution?”, "What stresses you in this job?”, and "What resources do you rely on in handling your work roles?”. Using this data strategy enabled us to obtain information about the shared experiences and norms of the caregiving work. The discussions also brought out corroborations and contradictions in experiences within that environment, highlighting the individuality or subjectivity of the experience of care. This enriched our data as it enabled us to obtain detailed descriptions of the care work and the subjective stressors and resources inherent in that work for individual workers.

\section{In-depth Interviews}

In order to increase the multiplicity of data sources, additional data were collected through in-depth, one-on-one interviews with participating caregivers selected through both the participant observations and focus group discussions. The interviews provided an opportunity to elicit information that might have been missed during the two previous data collection processes; moreover, they gave us the third set of data needed for triangulation. A total of 32 interviews were conducted at times and places convenient for the participants. Seven of the interviewees had been part of the focus group discussions. Interviews lasted an average of 1 hour and 43 minutes; the interview language was either English or Twi (a local Ghanaian language), depending on the preference of the participant.

\section{Ethics}

Ethical clearance was obtained from Norwegian Social Science Data Services (now the Norwegian Centre for Research Data) before data collection began. Additional permissions were obtained from the Department of Social Welfare of the Government of Ghana and the authorities in charge of the institutions where data were collected. Before participant recruitment began, the study, its purpose, participant rights to withdrawal, and rights to seek clarification were explained to all targeted participants. Those who agreed to participate were given informed-consent forms to sign before being recruited for participation. Audio recordings of all focus group discussions and interviews were made with the full written consent of the participants.

\section{Data Analysis}

We analyzed the data by first transcribing and translating the focus group discussions and interviews. A coding team consisting of three $\mathrm{PhD}$ candidates and the lead author was formed, and each member separately coded transcripts using the NVivo 10 software. Members then met to discuss the codes. Coding disagreements were discussed thoroughly until consensus was reached. We then conducted a systematic network analysis of the data following AttrideSterling (2001). This process yielded basic, organizing, and global themes. The global themes in this case are stressors (see Table 2) and resources (see Table 3). 
Table 2 Thematic Network Analysis of Data, Global Theme: Stressors

\begin{tabular}{|c|c|c|}
\hline Codes & Basic Themes & $\begin{array}{l}\text { Organizing } \\
\text { Themes }\end{array}$ \\
\hline $\begin{array}{l}\text { Children here challenge authority and refuse chores } \\
\text { Children do not listen to anything we tell them } \\
\text { Children fight a lot } \\
\text { Children refuse errands and talk back at caregivers }\end{array}$ & Difficult children & \multirow{2}{*}{$\begin{array}{l}\text { Child-related } \\
\text { stress }\end{array}$} \\
\hline $\begin{array}{l}\text { Difficult to bond with children } \\
\text { Children struggle to see us as parents } \\
\text { Paying equal attention to many children is difficult } \\
\text { Varying backgrounds of children makes it difficult }\end{array}$ & $\begin{array}{l}\text { Difficult care } \\
\text { worker-child } \\
\text { bonding }\end{array}$ & \\
\hline $\begin{array}{l}\text { Work overload and no rest } \\
\text { There is nothing about this job that is not stressful } \\
\text { We have to supplement with our own pocket money } \\
\text { We are powerless over the children; how can we raise them? } \\
\text { No training to handle mentally ill children }\end{array}$ & $\begin{array}{l}\text { Difficulty providing } \\
\text { care }\end{array}$ & \multirow[t]{2}{*}{ Job-related stress } \\
\hline $\begin{array}{l}\text { Shift schedule is only on paper } \\
\text { Caregiver-child ratio is 1:10 or more } \\
\text { You can't tell when you are going to close from work } \\
\text { You can't tell what you will be required to do on any day } \\
\end{array}$ & $\begin{array}{l}\text { Work ambiguity and } \\
\text { poor routine }\end{array}$ & \\
\hline $\begin{array}{l}\text { Caregivers are rushed to hospital often } \\
\text { High blood pressure is on the rise among us } \\
\text { Light-headedness and dizziness are common experiences here } \\
\text { Our health is deteriorating and no one cares } \\
\text { There is so much exhaustion here and no way out } \\
\text { Slips and falls are common experiences due to rush }\end{array}$ & $\begin{array}{l}\text { Poor employee } \\
\text { health and safety }\end{array}$ & \multirow{3}{*}{$\begin{array}{l}\text { Institutional and } \\
\text { work environment } \\
\text { stress }\end{array}$} \\
\hline $\begin{array}{l}\text { There is dissatisfaction and uncertainty about our pension } \\
\text { We have become sad and afraid } \\
\text { Employee mistrust and conflicts have become normal here } \\
\text { Fear of query for poor child dressing or lateness to school } \\
\text { Superiors reprimand caregivers in front of children } \\
\text { We fear secret recordings by visitors } \\
\text { The salary is nothing to write home about } \\
\text { Superiors betray us in the face of trouble }\end{array}$ & $\begin{array}{l}\text { Work environment } \\
\text { tensions and } \\
\text { mistrust }\end{array}$ & \\
\hline $\begin{array}{l}\text { You feel guilty of being bad parents following those laws } \\
\text { Too much child rights spoil the children and make them difficult } \\
\text { We are not allowed to be real parents } \\
\text { We just follow the rules } \\
\text { Children here don't know anything apart from their rights } \\
\text { UN training gives the children no sense of responsibility }\end{array}$ & $\begin{array}{l}\text { Confusion regarding } \\
\text { child rights }\end{array}$ & \\
\hline $\begin{array}{l}\text { When we leave they are sleeping, when we come back they are sleeping } \\
\text { I feel the gap between my children and me widening } \\
\text { Our families feel abandoned } \\
\text { I feel trapped }\end{array}$ & $\begin{array}{l}\text { Tension with and } \\
\text { alienation from own } \\
\text { family }\end{array}$ & \multirow{2}{*}{$\begin{array}{l}\text { Work-family } \\
\text { conflict and stress }\end{array}$} \\
\hline $\begin{array}{l}\text { I don't know if I can mix up with family again as I used to } \\
\text { Family thinks institution is rich because white men are involved } \\
\text { Family expects more financial contributions from me } \\
\text { Families do not really understand our work }\end{array}$ & $\begin{array}{l}\text { Family } \\
\text { misperception and } \\
\text { overexpectations }\end{array}$ & \\
\hline $\begin{array}{l}\text { They insult us for the children's bad behaviour } \\
\text { Everybody just pays attention to the children not us } \\
\text { Nurses insult us when we send sick children to hospital } \\
\text { I think they see us as child abusers }\end{array}$ & $\begin{array}{l}\text { Community apathy, } \\
\text { suspicion, and } \\
\text { mistrust }\end{array}$ & \multirow{2}{*}{$\begin{array}{l}\text { Community- } \\
\text { related stress }\end{array}$} \\
\hline $\begin{array}{l}\text { They treat us like criminals } \\
\text { Some say we just spoil the children and get paid for it } \\
\text { Donations have reduced, they think we are rich } \\
\text { Public opinion about us is demoralizing }\end{array}$ & $\begin{array}{l}\text { Negative community } \\
\text { opinion and } \\
\text { relations with care } \\
\text { workers }\end{array}$ & \\
\hline
\end{tabular}


Table 3 Thematic Network Analysis of Data, Global Theme: Resources

\begin{tabular}{|c|c|c|}
\hline Codes & Basic Themes & $\begin{array}{l}\text { Organizing } \\
\text { Themes }\end{array}$ \\
\hline $\begin{array}{l}\text { Children crack jokes and that relieves stress a little } \\
\text { Children dance and cheer } \\
\text { We laugh together as a family }\end{array}$ & $\begin{array}{l}\text { Humour and } \\
\text { stress relief from } \\
\text { children }\end{array}$ & \multirow{3}{*}{$\begin{array}{l}\text { Children as a } \\
\text { resource }\end{array}$} \\
\hline $\begin{array}{l}\text { Older children help at home sometimes } \\
\text { Prayers and support from former children } \\
\text { Some children are well-behaved and give ideas }\end{array}$ & $\begin{array}{l}\text { Children are a } \\
\text { resource }\end{array}$ & \\
\hline $\begin{array}{l}\text { I just like children } \\
\text { Seeing the children happy inspires me to work hard } \\
\text { When my children excel, I forget the stress in the job } \\
\text { My joy is in seeing the children grow and prosper }\end{array}$ & $\begin{array}{l}\text { Children are a } \\
\text { source of } \\
\text { inspiration }\end{array}$ & \\
\hline $\begin{array}{l}\text { We get things all right but we need more } \\
\text { When you need anything, you write a requisition and you get it if it's } \\
\text { available } \\
\text { We receive adequate household money to buy things for the household } \\
\text { They never let the children lack anything }\end{array}$ & $\begin{array}{l}\text { Adequate job } \\
\text { materials }\end{array}$ & \multirow{4}{*}{$\begin{array}{l}\text { Organizational } \\
\text { resources }\end{array}$} \\
\hline $\begin{array}{l}\text { We get frequent training } \\
\text { Officers assist us in this job sometimes } \\
\text { Social workers are here to provide support } \\
\text { In times of difficulty we call on the director, a social worker } \\
\text { The institution helps me get loans because I have a pay slip }\end{array}$ & $\begin{array}{l}\text { Institutional } \\
\text { support for } \\
\text { workers }\end{array}$ & \\
\hline $\begin{array}{l}\text { The institution has partner donors who provide resources for us } \\
\text { The office goes on air and to the banks to raise money during difficulty } \\
\text { Foreign organizations know this institution so they bring us things } \\
\text { Our thanks go to the donors, we work because of them }\end{array}$ & Donor support & \\
\hline $\begin{array}{l}\text { When there is a family emergency, I rely on them to cover me } \\
\text { I am supervisor but I don't sit down and watch them suffer, I join in } \\
\text { Mothers have a prayer team } \\
\text { We share our joys and pains together sometimes }\end{array}$ & $\begin{array}{l}\text { Worker-to- } \\
\text { worker support }\end{array}$ & \\
\hline $\begin{array}{l}\text { Because God watches over us, anytime I'm rushed to hospital, I come back } \\
\text { alive } \\
\text { God takes care of us } \\
\text { I receive God's blessings for doing this job } \\
\text { God touches people to give me things when I am in need } \\
\text { If you care for God's children, your sins will be forgiven } \\
\text { They did it to Jesus }\end{array}$ & $\begin{array}{l}\text { Religion as a } \\
\text { resource }\end{array}$ & \multirow{4}{*}{ Personal resources } \\
\hline $\begin{array}{l}\text { Some friends of mine pray with me for strength in this job } \\
\text { My church sisters encourage me } \\
\text { My own mother commends me all the time for doing this job } \\
\text { My husband is proud of me, he calls these children his children } \\
\text { You get some friends from the community encouraging you }\end{array}$ & $\begin{array}{l}\text { Family and } \\
\text { friends }\end{array}$ & \\
\hline $\begin{array}{l}\text { As long as I do this job, I have a comfortable place to live } \\
\text { There is prestige out there in working for this institution } \\
\text { I have a salary, even if it is small } \\
\text { This job helps me pay for my own children's education } \\
\text { Some caregivers don't have children so they came here to raise children for } \\
\text { themselves }\end{array}$ & $\begin{array}{l}\text { Economic and } \\
\text { social motivation }\end{array}$ & \\
\hline $\begin{array}{l}\text { Difficulties are there but I am stronger } \\
\text { I don't let difficulties get to me } \\
\text { They can say whatever they want, it won't stop me } \\
\text { My mother trained me to care for children } \\
\text { This is my job, I've got to do it }\end{array}$ & $\begin{array}{l}\text { Individual } \\
\text { characteristics }\end{array}$ & \\
\hline
\end{tabular}




\section{Findings}

Interesting findings reflecting stress-resource experiences that characterize the care work for workers in institutions for CWPC emerged through the analyses of the textual data. For clarity, these findings are presented here systematically in accordance with the basic, organizing, and global themes.

\section{Stressors}

Stress experiences recounted by caregivers in this context arose from many different aspects of the work and institutional environment. Sources of stress ranged from stressors related to the children in residence, through stressors associated with worker-to-worker relationships, employer-employee relationships, and institutional rules and routine. Other sources of stress were found in tensions in the relationships between caregivers and their biological families, and between caregivers and the communities within which their institutions are located.

Child-related stress: The children in residence were identified as a major source of stress by the caregivers. Beyond the usual difficulties associated with parenting children that arise even in family homes, the caregivers seemed to perceive the residential children as particularly difficult to handle for a range of reasons:

These children we are supposed to parent are not like normal, regular children. These ones are extra difficult to handle because they do not see you as their parent, and therefore can challenge your authority on any day.... They are government children, not yours. (Mother, 54 years old)

For some other caregivers, the difficulty in handling the children arises because they come from very different backgrounds:

You see, these ones are not biological siblings, so they don't share a bond ... in that case they fight a lot.... Look around, I have many children in this unit, I tell you, I defuse over 12 to 15 fights every day.... That leaves me exhausted after every working day. (Mother, 48 years old).

For another mother, the fights were not so much about lack of bonding; it was rather an ingroup versus out-group issue:

You know, in this institution, the policy is that biological siblings must always be kept together ... so, what you see happening is that occasionally, each set of siblings becomes a little "gang" defending themselves against the other "gangs". That is trouble, sir, it is so much trouble. (Mother, 51 years old)

Still other caregivers perceived the stress related to the children as stemming from the fact that the children have learnt about their rights and often take advantage of them to refuse chores and talk back to caregivers: 
What stresses me most about this job is when there is so much to be done in this house, and yet even the older children refuse to help with any chores.... In my own house, I could use my authority to get my children to do their chores ... but here, for fear of infringing on their rights, you just have to leave them and do everything yourself.... It’s not easy here. (Assistant mother, 43 years old)

Job-related stress: Caregivers also recounted experiencing stress coming from the characteristics of the job itself. For many of the workers, their jobs are ambiguous, poorly structured, poorly resourced, and overloaded, giving them no rest:

When you come to work, there is so much to do that you have no rest.... Just imagine two workers taking charge of 40 children ... you have to make sure they are all ready for school on time, that they have all eaten ... if even one of them falls sick and needs hospital attention, it means one worker has to go on hospital duty leaving only one remaining to take charge of the rest of the children. (Mother, 45 years old)

Another participant said:

What kills them in this job is that you just don't know what you will be expected to do when you report for work and you don't know when you will close.... You could be heading to hospital, to a school disciplinary hearing, running errands on the market, etc. ... the list is endless. ... You could simply spend the whole day trying to convince the office people to give you materials needed to run the home.... I just pity the mothers, they suffer a lot. (Social worker, 32 years old)

The complaint about materials needed to run the homes came almost entirely from the government institution. Another participant said:

I can't count to you the number of times I have had to use my own small salary to get things for these children.... These children have been trained to think that they should get everything they want, so if they come to you asking for something and you don't give it out, it's trouble ... and who knows what they will tell visitors ... before you know it, there is news in the media about how you are denying the children anything they ask for ... and the public will set upon you.... The stress here is just too much. (House father, 33 years old)

During focus group discussions, there was a general agreement that one of the most stressful aspects of the work is handling mentally ill children:

We don't even know if this is a Children's Home or a mental hospital.... We have no training handling children who are mentally ill, yet they keep bringing them in and we just don't know what to do with them.... There is one in my unit who chews the paint on the walls, and beats up almost all the small children every day.... Myself, I am afraid of him, because he has slapped me once. (Assistant mother, 36 years old) 
Institutional and work environment stress: Issues affecting the health and safety of caregivers in the institutional environment, as well as rules and regulations regarding child rights and how caregivers are expected to parent, were identified as key stressors. In addition, the institutional atmosphere seemed tense and there seemed to be a lack of trust between workers, and a wariness of visitors to the institutions:

We work in an environment where we don't know who to trust ... your fellow worker could be the one who tells a lie about you to the authorities.... I have become very careful these days.... When you get in trouble, no one has your back ... you are on your own. (Mother, 50 years old)

The participant observation phase of data collection in the government institution revealed some of this distrust of visitors, as most caregivers opted to stay away from the observing author and refused to communicate with him in any way. During focus group discussions, there was unanimous agreement in both institutions about concerns for health and safety. Some caregivers complained about lack of institutional support in seeking health care for workers:

With all this stress, what do you expect? ... High blood pressure is on the rise in this environment, ask anyone, they will tell you, and slips and falls are common ... it is normal here ... and if you need health care, you only have your salary to rely on. (Mother, 57 years old)

During the interviews, one resident nurse said:

They [caregivers] even need medical attention more often than the children here.... If you stand on your legs from 6 a.m. to 11 p.m., tell me, what do you think will happen to you? Lightheadedness, dizziness, and what have you.... When people hear that someone is being rushed to the hospital from here, they often think it is a child, but very often, it is a caregiver ... and who pays for it, they pay themselves. (Resident nurse, 49 years old)

Other caregivers, primarily from the private institution, praised their institution for being very helpful in supporting them during health emergencies but still complained about the level of health deterioration caused by the work:

Oh, everybody knows that in this institution, the authorities take our health matters very seriously.... In fact, they are very helpful in providing funds and resources ... but ... you may provide resources ten times for me if I am rushed ten times to the hospital, but the fact that I am being rushed that frequently means something has to be done about the job.... It is too stressful. (Mother, 51 years old)

The work environment, according to the workers, was also dominated by laws that some perceived as foreign. Almost everyone seemed confused by these laws, but felt compelled to obey them. These were child rights regulations that seemed to limit the extent of authority and control that care workers could exercise over the children — control that care workers felt was central to their role as parents: 
Just imagine this, you tell me to parent a child, and yet forbid me from disciplining that child.... How then do you expect me to be a parent? ... Does it make sense to you? (Social worker, 32 years old).

The caregivers' frustration at having to parent in accordance with child rights principles was demonstrated in focus group discussions, when some caregivers became emotional while narrating how some of their children in the institution would stand up to them, and say things that their biological children would never dare to:

How would you feel if a young child like that stood up to you, shouted obscenities at you, and walked out on you? ... [Wipes tears off face] ... Can my own child say that to me? ... This is what we have to endure in this environment ... because we need a job.... These children's minds have been poisoned with rights and we suffer the consequences. (Mother, 55 years old)

For some other caregivers, the concept of child rights confuses them and makes their work more difficult:

For me, I am even confused with this child rights thing ... ok, so the child has a right to do or refuse to do what I tell them, and every child has a right to be loved.... [laughs] ... How do you expect me to develop love for a child who does not respect me and who can choose to obey me or disobey me at no consequence? ... It's just funny.... I just leave them alone, it is they who will suffer when they eventually get out there and do not know how to show respect. (Assistant mother, 43 years old)

Interestingly, the prediction of suffering for institutional children who are rights-conscious was corroborated during interviews by two of the three participants who themselves were once CWPC and who were now volunteering in their respective institutions. One said:

Yes, that is very true, I didn't find it easy integrating during the first few months out there.... It just seemed like I was the only one who knew anything about child rights.... I got insulted when I tried to stop my neighbours from disciplining their children by spanking, and I found it difficult mixing up because everyone kept saying I didn’t respect ... (Former institutional child, 27 years old)

In one of the institutions, there were times when a particular superior officer would openly caution a caregiver in front of the children, asking her if she wanted the institution's name in the media for the wrong reasons. In a follow-up interview after one such incident, an administrative officer said:

It's not that we don't treat our workers well, but those who own and fund this institution expect us to use the rights approach, it's a condition upon which we receive funding ... so if any information gets in the media that the children are complaining, what do you think will happen to us? (Administrative officer, 49 years old) 
An educational worker in one of the institutions also demonstrated frustration with the dominance of "foreign" child rights laws as conditions for funding when he said:

You mean these children here? ... Yes, those UN rules don't teach them any sense of responsibility ... and the ways in which they want us to raise them too, sometimes it works, sometimes it doesn't work, so you just leave it at that ... because at the end of the day, that is what brings the funds to run this place. (Educational worker, 36 years old)

Work-family conflict and stress: Caregivers were also challenged by tensions within their biological families. The data collection process revealed a seeming unease in most caregivers when having to talk about their relationships with their families and how their work was impacting that relationship. There were accounts of feelings of alienation and distrust on the part of both caregivers and their families. Family misperception about the care work and overexpectation of the monetary rewards associated with that work were also reported:

Hmm ... well that is a problem I am struggling to deal with right now... Y You see, when I leave for work, everyone is sleeping, when I come back, everyone is sleeping ... and on weekends, there is no guarantee that I will not be called for work... From the way my children react to me, I feel like they don't know me any more. (Assistant mother, 47 years old)

For another caregiver, the work was creating distrust between herself and her husband and putting strain on their marriage:

Let me ask you this: If your wife went to work at dawn and came back late at night from Monday to Saturday, wouldn't you even think she has been passing behind to see another man under the cover of work? ... Well, that is what I'm being accused of every now and then ... but I also hit back often, because while I'm away at work, I don't know what's happening behind my back ... if some woman has been coming into my house, how would I know? ... It's putting strain on the marriage, but I know God will save this marriage for me [Wipes tears off face]. (Mother, 53 years old)

Through informal conversations during the participant observation phase, some caregivers shared experiences in which they had been asked to pay more during an extended-family contribution for a funeral or other occasions because they work with white people:

Sometimes it's sad, sometimes it's just funny ... I mean you can't help laughing.... Can you believe that one of my uncles died and during contributions for the funeral, I found out that I was being punished with a bigger contribution because I didn’t attend family programs regularly? ... When I complained, they said I should pay more because I work with white people and have money. (Mother, 53 years old) 
One mother recounted, through tears, how her children accused her of abandoning them to care for other people's children and how that realization made her feel trapped in her current situation:

Well, this has been my dilemma, this has been my burden, my children confronted me once.... I work hard here to earn my salary and send to them, but they accuse me of abandoning them to care for other people's children. [Wipes tears] ... Can you blame them? ... And if I stop, what are we going to eat at home? ... I feel trapped. (Mother, 45 years old)

Participant observation revealed that while one of the institutions organized the work in shift schedules, the other had a policy of permanent stay for all mothers, with a certain number of leave days per month for family visits. However, it was clear that neither system was ideal. The shift schedule never really worked as planned. The workers complained that they often had to keep working even when their shifts were over because the incoming mothers were ill and unable to make their shifts. "Hospital duty", when a caregiver had to stay with a child being admitted to hospital, also often kept them from returning home after their shifts. With regard to the leave policy, there was a clause attached requiring the caregiver to find a replacement before taking leave, but due to a shortage of replacements, caregivers rarely could actually take the leave owed them. While there were provisions for caregivers' biological children to pay them visits on the institutional compounds, male children were not allowed to sleep over; this restriction also applied to spouses. According to institutional authorities, the restriction was aimed at preventing potential sexual abuses of the children, especially the girls.

Community-related stress: Caregivers also reported experiencing stressors in the communities within which the institutions were located. Under normal circumstances, Ghanaian social norms lead people to empathize with vulnerable children and their caregivers, and, if possible, make donations to support them. While such empathic ways were still being practised in the communities where the participating institutions in this study are located, caregivers thought the extent of community support was dwindling. Participant observation data revealed that, for the private institution especially, this was probably because of a widespread perception that the institution received funds from foreign donors and was therefore rich, with the children in residence being better off than the ones living in their family homes in the local community. Indeed, the landscape of the institutional environment, the children's clothing and general outlook, the type of family homes built for the mothers and their children, and the general facilities in the institution that mothers and their children could access were in a far better state than those in the local community, as the observing author noted.

For some caregivers, this was creating a kind of animosity between the institution and the community, with some community members often accusing the children at the private institution of looking down on the local community children:

Well as you can see, our children here are better clothed, better housed, and better fed than those in the local community ... just look around.... How do you expect them [the community] to see the children here as vulnerable? ... And of 
course, some of the children here act it out when they go to the community ... you know children ... and that makes us targets of hostility in the community, though not very often. (Social worker, 53 years old)

An administrative worker at the private institution recounted an experience where a local church came to donate some items and ended up taking those items back:

You know we can't allow these vulnerable children to just live like the CWPC that they were before they came here.... Our mandate is to provide for them the kind of care that they never had.... I tell you ... a church came here to donate some clothing and when they came and saw how our children here were dressed, their leader told me they were taking their items back because it didn't even match what our children were already wearing ... so you see ... it's a difficult situation.... Somehow doing the right thing has become a case for judging you. (Administrative worker, 49 years old)

During participant observation, an informal conversation with one 16-year-old residential child seemed to corroborate this. The child expressed pity for the local community children and said he kept some of his own food and gave it to his friends from the community when they came to school hungry. He recounted how some of his friends from the community got expelled from school for non-payment of fees, and ended up not going back. The question thus arises as to which child really was the vulnerable one, the institutional child or the child from the community?

For the government institution, the challenge in the community for the caregivers was a seeming community perception that those caregivers were just getting paid to spoil the children:

Some of them think we are just here to spoil the children with some foreign laws and get paid for it ... but for us, we know it's the rules of the job ... so we don't blame them so much. (Mother, 53 years old)

Another caregiver said:

It's demoralizing when you make all these sacrifices to care for these children and the community treats you this way. They think we are thieves who just steal materials meant for these children for our own children ... especially since that Anas case ${ }^{1}$ happened. (Assistant mother, 50 years old)

Additionally, the attitudes of local hospital nurses towards caregivers who accompanied sick residential children needing medical attention was also described as stressful:

What I hate is hospital duty.... Those nurses there don't think anything good of us, you face all sorts of insults and sarcasm ... because they think we mistreat

\footnotetext{
${ }^{1}$ The "Anas case" was an undercover investigative journalist's report alleging caregiver corruption and abuse of children in some children's homes in Ghana.
} 
the children and steal things meant for them ... they just treat us like criminals. (Mother, 54 years old).

An employee in the administration department of one institution said:

For me, I don't see that anybody cares about these mothers ... everything is about the children ... but I tell you, their work is so difficult.... It kind of makes them feel unappreciated, you know ... because when something happens, they won't take time to investigate, they just blast them in the media. (Administrative worker, 54 years old).

\section{Resources}

Facing daily stressful circumstances in the workplace was not the only experience shared by the caregivers who participated in this study. Amidst all the stress, there were accounts of resource experiences that made positive contributions to the caregivers' ability to continue with the work. Interestingly, the very sources that produced the stressors recounted were also identified and utilized as resources, according to caregiver accounts. However, the discussions about resource availability and utilization revealed notable differences between caregivers regarding the extent to which the sources of stress also became resources for them. These differences were largely associated with whether they worked in the private or the government institution.

Children as a resource: After describing the children in their care as "difficult" and a key source of stress in their work, caregivers shared experiences in which the same children were portrayed as resources that motivated them to keep working and helped them to cope with stress. For some, just the sight of their children "doing well” inspired them to keep working. Some felt they received support from the children's prayers. Others described some of the children in their care, especially the very young ones, as "funny", "adorable", and a source of humour and stress relief from daily tensions in the work:

I would say these same children are resources ... you see, especially the little ones in kindergarten, they make you laugh a lot.... When they come back from school and begin to sing those kindergarten songs and begin dancing, oh my God, it's so adorable and sweet ... you tend to forget all the stress momentarily. (Mother, 53 years)

Some caregivers thought some of their children were important resources because they helped with basic house chores:

Well, it is not as if all the children are so bad or difficult.... You see, among them all, you find some two or three being very helpful with chores that the majority of them refuse to do under the cover of their rights ... so some of them are resources for us as well. (Assistant mother, 47 years old)

For another participant, it is her former residential children who are now living independently that serve as resources for her: 
The children that I have raised to become adults and who are now living and working in the cities, they are my resources.... Last time when I was rushed to hospital, one of them came to help pay my bills; another time, one of them came here with a lot of foodstuffs for me. Seeing them doing so well on their own inspires me and makes me forget about all this stress.... I will never give up on this job. (Mother, 57 years old)

It became clear during the participant observations and later focus group discussions and interviews that descriptions of the children as a resource were more frequent among care workers in the private institution. Government institution workers tended to rate the working conditions of workers in the private institution as better when it came to children helping with chores:

You see, this place is not like the other rich private children's homes.... There, the mothers live in a home with their assigned children like a family ... so they are able to get the children to help them because the bond is stronger ... but here, it's like a boarding house, just look at the numbers ... so they don't help. (Mother, 53 years old).

Another government institution worker described the children as being a resource in a way that was different from how the private institution workers saw it:

Well, I can say that the children are resources for some of us.... It's not like they help us to do the job in a physical way ... but when you see them running around and happily playing in the compound, and you cast your mind back to how they looked when they first came, it kind of makes you proud of what you have accomplished with them. That in itself is an inspiration that keeps you going. (Assistant mother, 49 years old)

Organizational and institutional resources: Though caregivers encountered stress in every aspect of their work, there were also instances in which they recounted deriving resources from their institutions. This helped them remain productive and healthy despite the stress. Again, there were significant differences between workers from the two institutions. In most cases, caregivers from the private institution had more to say about positive practices in their institution that helped them stay healthy and productive, while the government workers had little to say in this regard. For example, a private institution worker said:

The office does very well, they never make the children lack anything ... as soon as you request, they strive to provide for you ... so we cook and eat what we want.... If a mother or worker gets a funeral, the office bus is made available and they give you the support you need. (Mother, 50 years old)

In contrast, a government institution worker had this to say:

Well, the resources we get from this institution are not much.... Often, we even have to support the children with our own salaries ... you see, because sometimes the money from the government delays, and that means we 
experience shortage of materials needed to run the place ... and the office people too sometimes think we misuse the things, so you will have to talk and talk before they give you one thing. (Mother, 54 years old)

Thus, while workers from both institutions generally agreed that their institutions provide support, the differences were in the extent of support provided.

Caregivers from the private institution agreed during focus group discussions that they received frequent training on how to handle their duties well:

Oh sure, they train us frequently ... they are very good at it.... We are even about to embark on a training program next week.... They teach us about child rights and how to deal with some of the difficulties ... the problem is that it is difficult to teach a person how to do a job meant for three people, alone. (Mother, 51 years old)

Meanwhile, caregivers from the government institution agreed that they barely had any training:

Well, I can say I have attended two training sessions in my 15 years here ... so yes ... they train us but not much. (Mother, 54 years old)

Workers from both institutions did agree during focus group discussions and informal conversations that the social workers and their respective institutional directors have been important resources for them in times of difficulty in various ways.

One other resource that was mentioned by workers from both institutions was donor support. Indeed, all participants confirmed that donor support was the major lifeline of their organizations and that the resources provided by donors were key in helping them cope with the work and remain productive:

You see, sometimes when we are short of materials and the mothers have brought in so many requisitions, it becomes stressful for me as the head here because the responsibility ultimately falls to me, but God being so good, in moments like that you see donors walk in from nowhere to donate the same items that were needed so bad.... That is a resource that reduces the stress for me and the mothers as well. (Institutional head, 53 years old)

Another participant said:

Well, thanks to our donors ... those who come from their hearts to donate to this home so we can breathe a sigh of relief in this job ... it is because of them that we are able to do our jobs. (Assistant mother, 49 years old)

Again, despite earlier accounts of tension and mistrust between coworkers, there were reports of workers supporting each other in their daily activities. Indeed, it was observed during participant observations that some caregivers had formed a prayer group and periodically met to pray together. After a prayer session, one mother said: 
Well, if you find yourself in this job, you will realize that you cannot do without prayer and you cannot do without one another.... So yes, tensions may be there, but we still manage to be resources for ourselves and each other. (Mother, 59 years old)

Another said:

When I attend these meetings, it renews my spirit because I become convinced that God will take care of me and I am able to carry on.... Without this, I don't know if I would still be working here. (Assistant mother, 47 years old)

Personal resources: The children and elements within the institutional environment were not the only resources that caregivers managed to identify and utilize in their work roles. Reaching deep into themselves and finding strength and motivation from personal convictions seemed to be the strongest resource that almost every participating caregiver relied on. From religious convictions to economic motivation, from a sense of self-efficacy to a quest for selffulfillment, caregivers shared experiences that clearly revealed that their greatest resources were themselves:

My faith in God as a Christian is my greatest resource.... God blesses me for taking care of these vulnerable children.... Knowing that I am doing something that pleases God is all that I need to go on in this job. (Mother, 51 years old)

Another said:

I know that God loves me because I love these little ones.... That alone inspires me to stay in this job and forget about the stress. (Assistant mother, 43 years old)

With all participants except one identifying as Christian, the perception that doing what is necessary to help the children grow is a duty assigned by God seemed to be one to which almost all caregivers subscribed. Thus, faith was a strong personal resource identified and utilized by caregivers.

Some caregivers considered the care work as something that they were very capable of doing because of skills they had acquired through their experiences of parenting their own children. For these workers, their personal experiences and capabilities were their key resources in the job:

I joined this work after all my children entered tertiary education. When you have had that much experience of parenting four children to their adult ages, you realize that there is no job you can do better than parenting children. I rely on my experience a lot in this job. (Mother, 57 years old)

Also, a quest for self-fulfillment and the attainment of that fulfillment became a resource for some other caregivers: 
In our part of the world, a woman is not fulfilled until she has had children and raised them.... Well, I wasn't fortunate enough to have my own children and I lost a marriage because of that, but I was determined to experience motherhood, and doing this job has given me that experience. I consider myself fulfilled and this is a resource that makes me find this job easy to do, especially when the children see me and run to hug me shouting, "Mother! Mother!" (Mother, 53 years old)

Other caregivers felt that the economic benefits they obtained from working for their institutions made them always strive to be innovative in handling their work duties and by so doing become resources themselves:

I earn a living by doing this job.... There are countless jobless people roaming the streets ... so I always try to be innovative, think of options around situations that crop up in this job and find solutions.... That helps me keep this job ... it always works. I consider myself a resource. (Father, 34 years old)

Thus, it became clear that while caregivers experienced different forms of stress at different levels of their jobs and organizational environment, some of the sources of stress were also seen as sources of resources that helped them cope. It also became clear that the experience of resources differed significantly among care workers depending on the type of institution they worked for.

\section{Discussion}

A complex web of work stress and resource experiences, subjective or shared, emerged in our findings. The participant accounts show how caregivers understand, make meaning of, and manage the care work situation. In terms of the salutogenesis theoretical framework that inspired the study, this demonstrates how the elements of comprehensibility, manageability, and meaningfulness play out for workers in the line of duty. We therefore discuss the findings in accordance with these elements.

\section{Comprehensibility}

Our findings indicate a general sense of comprehensibility of the work situation and the work environment on the part of caregivers. This is evident in participant accounts which demonstrate clear consistency in the types, nature, and sources of stress confronting them. For example, themes such as the children, child-rights principles, relations with fellow workers and the local community, and work-family conflict consistently emerged as key sources of stress across the institutions. From the salutogenic point of view, the consistency in participant accounts regarding what is stressful for them in their line of work is indicative of the level of predictability of the work environment for caregivers. For example, the fact that caregivers regularly experienced children challenging their authority, having to care for too large a group of children, and mistrust and apathy from the community demonstrates a pattern of consistency and predictability that gives caregivers an understanding of what to expect and a readiness to draw on available resources to cope. Thus, while the consistency of stress is not helpful and 
does not in any way make the work better, from a salutogenic standpoint, it helps caregivers understand the patterns of stressors in their work, giving them a chance to prepare mentally to face the challenge. It also puts caregivers in a position of knowledge of the complexities of their work and therefore able to assist when interventions are required. For example, should stakeholders decide to design training programmes for caregivers, the caregivers themselves would be able to help with information on what to include in the training content, considering that they know better which aspects of their work they need help with. This level of comprehensibility is an important step towards developing the SOC needed to move towards health despite the stress (Antonovsky, 1993; Eriksson \& Mittelmark, 2017).

It should, however, be noted that the level of employee comprehensibility of the workplace does not in any way reduce the tremendous amount of stress to which caregivers are exposed. Comprehensibility is not an excuse for the failure of stakeholders to reduce the stress levels. The consistent presence of stress in that work environment is a cause for concern. This confirms findings from Castillo et al. (2012) and Akpalu (2007) regarding resource shortages and inadequate support services in CHs, such as insufficient training for caregivers.

Our findings also show that worker-worker, employee-employer, and institutioncommunity relationships were fraught with mistrust and suspicion, as was the relationship between caregivers and their own families. This could affect the crucially necessary cooperation, both intra-institutional and between the institution and the community, needed for the institution to run smoothly. Occupational health- and workplace health-promotion literature provides considerable evidence that suggests that this cooperation is key in determining the nature of work outcomes (see Brown, Gray, McHardy, \& Taylor, 2015; Brunetto, FarrWharton, \& Shacklock, 2010; Hegar, 2012). Evidence from work-family conflict research also suggests that the observed frictions between care workers and their families have the potential to affect employee outcomes such as work commitment (Benligiray \& Sönmez, 2012; Malik, Awan, \& ul-Ain, 2015). Our findings suggest a need for intervention to improve work relations between institutional leaders and core caregivers, as well as among caregivers themselves. The caregivers' evident comprehensibility of the care situation and environment shows their awareness of what the key issues are in their work situation, which puts them in a position to make important contributions to intervention attempts to support them. The design and implementation of any such interventions should therefore consider involving the full participation of the caregivers.

\section{Manageability}

Despite the stress, some caregivers demonstrated a sense of manageability of the work situation. Within the realm of salutogenesis, the concept of manageability is tied to perceptions of availability of resources in the environment and depends on individuals' ability to identify and utilize existing resources (both internal and external) to deal with the challenges at hand (Eriksson \& Lindström, 2008; Eriksson \& Mittelmark, 2017; Hanson, 2007). Our findings confirm this. We observed that key internal resources such as faith or religious conviction, values, and motivations were consistently identified and drawn on to manage the stressful work environment. We also found that some caregivers seemed able to pick out existing external 
resources to manage the prevailing stressors. In general, this was easier for employees in the private organization, which tended to have more resources available than the government organization. Most caregivers for the private organization were able to identify and utilize the "few helpful children" out of the general bunch of "rights-conscious" and therefore "difficult" children. Private $\mathrm{CH}$ caregivers also seemed better able to draw on their training and work out inter-employee differences to foster better cooperation and support. With their organization partly paying for their healthcare, caregivers for the private organization seemed better off than those in the government organization. Thus, the private $\mathrm{CH}$ workers had a higher sense of manageability and tended to experience the care work more positively than the government $\mathrm{CH}$ workers..

The implication here is that where more resources are available and used, workers tend to manage stress better. This is a confirmation of earlier stress-resource research outcomes (e.g., Bakker \& Demerouti, 2007; Hyvönen, Feldt, Salmela-Aro, Kinnunen, \& Mäkikangas, 2009). The finding also supports earlier findings by Baffoe and Dako-Gyeke (2013) and Darkwah, Daniel, and Asumeng (2016) that suggest a need to provide more resources such as training for caregivers in CHs, especially those in the government sector. For example, training caregivers in methods of encouraging the older children to help with chores while remaining within the framework of child rights would be quite helpful. By learning ways to regulate a child's behaviour using approaches other than smacking or beating, caregivers could achieve desirable results while still respecting the children's rights. Perhaps caregivers would then see child rights principles from a more positive perspective, helping to reduce the perceptions of stress attributed to the United Nations Convention on the Rights of the Child.

Further, our findings suggest that aside from providing more resources, an alternative way to support employees in this context, and perhaps other work contexts, would be to build their capacity to identify and utilize available resources. This is in line with the salutogenesis argument that people move towards health when they are able to identify and utilize resources available in their environments. In other words, an increase in resources would not necessarily help reduce stress on caregivers by itself; in order for the increase to help, caregivers must be able to identify and utilize the resources. We recommend that CWPC care institutions and perhaps other work organizations pay more attention to employee capacity-building in this regard.

The resources inequality observed here between the public and the private institutions is congruent with findings from Hearle and Ruwanpura (2009), who reported that bureaucratic and other delays in government processes often put government-funded care institutions at a disadvantage, leaving them with fewer resources and making the work more difficult for caregivers. In order to adequately address this situation, stakeholders, both local and international, may need to pay attention not only to the children in residence but also to the working conditions of the caregivers. Improved working conditions will have direct positive consequences for the health and wellbeing of both workers and children. 


\section{Meaningfulness}

In the midst of the stressful work environment, most caregivers still seemed to derive meaning from the work they do and seemed to believe that the effort they expended to engage with the stressors was worth it. Caregivers seemed to derive an intrinsic sense of satisfaction when the children excelled academically, and worked from a belief that doing care work is religiously and morally right. Within the salutogenesis framework, this implies strength in the face of adversity, which indicates a positive move towards health despite prevailing stressful conditions. This finding confirms earlier research that has reported that religious convictions about one's job orchestrate psychological conditions of meaningfulness and renew motivation, which in turn influences work engagement (Park, 2012; Rothmann \& Buys, 2011; Saks, 2011). This also supports the conclusion of Paloutzian, Emmons, and Keortge (2010) that employees who are motivated by religious interpretations of their work roles invest more time, energy, and commitment towards achieving work goals.

Our findings also reveal that those caregivers who saw the job as an opportunity to achieve the status they wanted gained a sense of personal accomplishment. Some caregivers tended to relish the challenge of the mothering role in order to satisfy a need to prove themselves equal to a social role of which others thought them incapable. Thus while their work provides them with the means to make a living, it also helps them to fulfill a social goal. These beliefs and feelings have the potential to be good foundations upon which institutional leaders and stakeholders could build to further improve caregiver resilience in the work context.

While our findings point to actions that can be taken to reduce the stress levels in residential child care work, opportunities have also been identified for measures to be put in place to increase the moral, religious, and intrinsic values of this work. Training, resourcing, and capacity-building to increase caregiver motivation and satisfaction could help provide some buffers against the prevailing stressors in this work environment. These suggestions are supported by motivation research outcomes that show positive relationships between employee incentive and work performance (Ibrahim \& Brobbey, 2015; Sekhar, Patwardhan, \& Singh, 2013). To the extent that caregivers who demonstrated this sense of meaningfulness seemed less likely to give up and were willing to keep going in the job, our findings also confirm those reported by Geldenhuys, Łaba, and Venter (2014) and Rosso, Dekas, and Wrzesniewski (2010), who reported positive relationships between psychological meaningfulness of work and work commitment.

\section{Impact on the children in residence}

The implications of our overall findings for the children, who are the key "outcomes" of the work of caregivers, is best discussed in connection with the sociocultural context within which the care service is provided. In the Ghanaian sociocultural context, children described with some of the attributes mentioned in our findings (e.g, difficult, quarrelsome, disrespectful, challenging authority) are generally tagged as "bad children” for whom disciplinary measures including corporal punishment are acceptable (Kyei-Gyamfi, 2011). These kinds of caregiver perceptions of the children could possibly trigger handling or responses that may not be in the 
children's best interests. Against the background of previous revelations made by investigative journalists that appear to show physical abuses of CWPC in CHs in Ghana (Adongo, 2011; Anas, 2010, 2015), our findings suggest that for the sake of the children there is need for debate about possible interventions to address caregivers' negative perceptions and beliefs about the children in their care.

Further, beyond the $\mathrm{CH}$ environment, our findings suggest a need for policy review regarding the organization and resourcing of CWPC care institutions. This supports earlier arguments by Engle et al. (2011) who call for support for care institutions for CWPC as part of the care continuum. Implementation styles and processes of Western-backed approaches to child care in the local contexts should also be reviewed. Beyond the Ghanaian context, our findings suggest that an approach that respects the cultural context and local norms, and that specifically involves parents and other concerned adults in design and implementation, could significantly promote the effectiveness of introducing the principles and practices of international conventions to local populations. This could help prevent feelings of encroaching western hegemony that often trigger resistance from local populations. As can be seen from our findings, the popular perception seems to be that child rights are foreign and are being forced on local caregivers under the cover of funding. The rights-based approach to parenting, which is crucial in these institutions, is thus being experienced as a source of stress instead of as a resource.

\section{Limitations}

This study adopted a qualitative approach to explore the general subjective experiences of workers within a specific occupational, social, and cultural context. Because we utilized techniques such as participant observation, the roles of the researchers in generating and interpreting the data limit its objectivity. Further, only two CHs participated in this study; therefore the evidence generated may best apply to the location where the study was conducted. Cross-context generalization of the findings should be done with caution though lessons learnt from it could apply to other similar contexts, especially in the sub-Saharan African region. The limited generalizability here also implies that it may be unsafe to draw general conclusions about differences between private and government institutions on this evidence.

\section{Conclusion}

This study was conducted to explore stress-resource experiences of CWPC caregivers in the context of CHs in Ghana. We found sources of stress experienced by caregivers to include the children in residence, interpersonal relationships at work, child rights regulations, institution-community relations, and relationships between caregivers and their own families. Interestingly, at all levels of the work environment, there seemed to be aspects that served both as stressors and resources for caregivers. It was found that some of the children and certain agents in the work environments, such as social workers and administrative workers, were key resources for the caregivers. Religious and moral convictions, as well as personal, intrinsic motivations to engage in the work, emerged as the sources of support and meaning most generally reported by the caregivers. We also observed that some workers exhibited SOC, 
demonstrating the components of comprehensibility, manageability, and meaningfulness of the work and the work situation, which seemed to help them develop a sense of wanting to go on. Our findings suggest a need for interventions focusing especially on reducing stress levels and on improving intra-institutional relations and cooperation both among workers and between core caregivers and institutional superiors. Such interventions should also target improving institution-community relations and reforming policy to allow workers more contact with their own families to reduce work-family conflict. We also encourage more debate and further research on local implications of strategies adopted to enforce international conventions such as the United Nations Convention on the Rights of the Child. Finally, we believe that our findings reveal an opportunity for institutional leaders and stakeholders to develop interventions to help caregivers increase their intrinsic sense of satisfaction through training and capacity-building. 


\section{References}

Adongo, S. T. (2011). Realising the rights of children in Ghana: Towards homes without walls. Paper presented in the second working group of the Way Forward Project, Addis Ababa, Ethiopia, May 24th to 27th.

Akpalu, D. A. (2007). Adoption of children and the contribution of the Osu Children's Home in Ghana. Children and Youth Services Review, 29(2007), 1070-1084. doi:10.1016/j.childyouth.2007.02.004

Anas, A. A. (2010). Orphan's home of hell. Retrieved from https://www.youtube.com/watch?v=KP__ gjW4vc

Anas, A. A. (2015). 'CARE'less: The devil and the orphanage. Retrieved from https://www.youtube.com/watch?v=6-vEmlFhhsc

Antonovsky, A. (1993). The structure and properties of the sense of coherence scale. Social Science and Medicine, 36(6), 725-733. doi:10.1016/0277-9536(93)90033-Z

Attride-Stirling, J. (2001). Thematic networks: An analytic tool for qualitative research. Qualitative Research, 1(3), 385-405. doi:10.1177/146879410100100307

Baffoe, M., \& Dako-Gyeke, M. (2013). Social problems and social work in Ghana: Implications for sustainable development. International Journal of Development and Sustainability, 2(1), 347-363.

Bakker, A. B., \& Demerouti, E. (2007). The Job Demands-Resources model: State of the art. Journal of Managerial Psychology, 22(3), 309-328. doi:10.1108/02683940710733115

Benligiray, S., \& Sönmez, H. (2012). Analysis of organizational commitment and workfamily conflict in view of doctors and nurses. The International Journal of Human Resource Management Decision, 23(18), 3890-3905. doi:10.1080/09585192.2012.665063

Bettmann, J. E., Mortensen, J. M., \& Akuoko, K. O. (2015). Orphanage caregivers' perceptions of children's emotional needs. Children and Youth Services Review, 49, 7179. doi:10.1016/j.childyouth.2015.01.003

Brauchli, R., Jenny, G. J., Füllemann, D., \& Bauer, G. F. (2015). Towards a Job DemandsResources Health Model: Empirical testing with generalizable indicators of job demands, job resources, and comprehensive health outcomes. BioMed Research International, 2015, Article ID 959621, 12 pages. doi:10.1155/2015/959621

Brown, S., Gray, D., McHardy, J., \& Taylor, K. (2015). Employee trust and workplace performance. Journal of Economic Behavior \& Organization, 116, 361-378. doi:10.1016/j.jebo.2015.05.001 
Brunetto, Y., Farr-Wharton, R., \& Shacklock, K. (2010). The impact of supervisorsubordinate relationships on public and private sector nurses' commitment. Human Resource Management Journal, 20, 206-225. doi:10.1111/j.1748-8583.2009.00117.x

Castillo, J. T., Sarver, C. M., Bettmann, J. E., Mortensen, J., \& Akuoko, K. (2012). Orphanage caregivers' perceptions: The impact of organizational factors on the provision of services to orphans in the Ashanti Region of Ghana. Journal of Children and Poverty, 18(2), 141-160. doi:10.1080/10796126.2012.710484

Chenoweth, D. H. (1998). Worksite Health Promotion. Champaign, IL: Human Kinetics.

Creswell, J. W. (2009). Research design: Qualitative, quantitative and mixed methods approaches. . Los Angeles, CA: Sage.

Darkwah, E., Daniel, M., \& Asumeng, A. (2016). Caregiver perceptions of children in their care and motivations for the care work in children's homes in Ghana: Children of God or children of white men? Children and Youth Services Review, 66(C), 161-169. doi:10.1016/j.childyouth.2016.05.007

de Jonge, J., Le Blanc, P. M., Peeters, M. C. W., \& Noordam, H. (2008). Emotional job demands and the role of matching job resources: A cross-sectional survey study among health care workers. International Journal of Nursing Studies, 45, 1460-1469. doi:10.1016/j.ijnurstu.2007.11.002

Demerouti, E., Bakker, A. B., Nachreiner, F., \& Schaufeli, W. B. (2001). The job demandsresources model of burnout. Journal of Applied Psychology, 86(3), 499-512. doi:10.1037/0021-9010.86.3.499

Department of Social Welfare. (2015). Why not orphanages? Accra, Ghana. Retrieved from http://www.ovcghana.org/why_not_orphanages.html

Engle, P. L., Groza, V. K., Groark, C. J., Greenberg, A., Bunkers, K. M., \& Muhamedrahimov, R. J. (2011). The situation for children without parental care and strategies for policy change. In R. B. McCall, M. H. van IJzendoorn, F. Juffer, C. J. Groark, \& V. K. Groza (Eds.), Monographs of the Society for Research in Child Development, 76(4), 190-222. doi:10.1111/j.1540-5834.2011.00633.x

Eriksson, M., \& Lindström, B. (2008). A salutogenic interpretation of the Ottawa Charter. Health Promotion International, 23(2), 190-199. doi:10.1093/heapro/dan014

Eriksson, M., \& Mittelmark, M. (2017). The sense of coherence and its measurement. In M. Mittelmark, S. Sagy, M. Eriksson, G. F. Bauer, J. M. Pelikan, B. Lindström, \& G. A. Espnes (Eds.), The Handbook of Salutogenesis. Basel, Switzerland: Springer International Publishing. doi:10.1007/978-3-319-04600-6

Freidus, A. (2010). Raising Malawi's children: Unanticipated outcomes associated with institutionalized care. Children \& Society, 24, 293-303. doi:10.1111/j.10990860.2010.00313.x 
Gakovic, A., \& Tetrick, L. E. (2003). Psychological contract breach as a source of strain for employees. Journal of Business and Psychology, 18(2), 235-246. doi:10.1023/A:1027301232116

Geldenhuys, M., Łaba, K., \& Venter, C. M. (2014). Meaningful work, work engagement and organisational commitment. SA Journal of Industrial Psychology, 40(1). $\underline{\text { doi:10.4102/sajip.v40i1.1098 }}$

Green, J., \& Thorogood, N. (2014). Qualitative Methods for Health Research. London, UK: Sage.

Groark, C. J., Muhamedrahimov, R. J., Palmov, O. I., Nikiforova, N. V., \& McCall, R. B. (2005). Improvements in early care in Russian orphanages and their relationship to observed behaviors. Infant Mental Health Journal, 26, 96-109. doi:10.1002/imhj.20041

Hanson, A. (2007). Workplace health promotion: A salutogenic approach. Bloomington, IN: AuthorHouse.

Hearle, C., \& Ruwanpura, K. N. (2009). Contentious care: Foster care grants and thecaregiver-orphan relationship in KwaZulu-Natal Province, South Africa. Oxford Development Studies, 37(4), 423-437. doi:10.1080/13600810903305240

Hegar, K. W. (2012). Modern human relations at work (11th ed.). Mason, OH: Cengage Learning.

Huhtala, M., Feldt, T., Lämsä, A.-M., Mauno, S., \& Kinnunen, U. (2011). Does the ethical culture of organisations promote managers' occupational well-being? Investigating indirect links via ethical strain. Journal of Business Ethics, 101, 231-247. doi:10.1007/s10551-010-0719-3

Hyvönen, K., Feldt, T., Salmela-Aro, K., Kinnunen, U., \& Mäkikangas, A. (2009). Young managers' drive to thrive: A personal work goal approach to burnout and work engagement. Journal of Vocational Behavior, 75, 183-196. doi:10.1016/j.jvb.2009.04.002

Ibrahim, M., \& Brobbey, V. A. (2015). Impact of motivation on employee performance: The case of some selected microfinance companies in Ghana. International Journal of Economics, Commerce and Management, III(11), 1218-1236.

International Labour Organization. (2012). Stress prevention at work checkpoints: Practical improvements for stress prevention in the workplace. Retrieved from http://www.ilo.org/global/publications/ilo-bookstore/orderonline/books/WCMS_168053/lang--en/index.htm 
Johnson, D. E., Guthrie, D., Smyke, A. T., Koga, S. F., Fox, N. A., Zeanah, C. H., \& Nelson, C. A., III. (2010). Growth and associations between auxology, caregiving environment, and cognition in socially deprived Romanian children randomized to foster vs ongoing institutional care. Archives of Pediatrics and Adolescent Medicine, 164, 507-516. doi:10.1001/archpediatrics.2010.56

Kyei-Gyamfi, S. (2011). Corporal punishment in Ghana. In R. K. Ame, D. L. Agbenyiga, \& N. A. Apt (Eds.), Children's rights in Ghana: Reality or rhetoric. Plymouth, UK: Lexington Books.

Malik, S., Awan, G. A., \& ul-Ain, Q. (2015). Role of work family conflict on organizational commitment and organizational effectiveness. Arabian Journal of Business and Management Review (Nigerian Chapter), 3(3), 115-126.

Manful, E., Takyi, H., \& Gambra, E. (2015). Admission to exit: Acquiring life skills whilst in residential care in Ghana. Social Work and Society, 13(2).

Michie, S. (2002). Causes and management of stress at work. Occupational and Environmental Medicine, 59, 67-72. doi:10.1136/oem.59.1.67

National Institute for Occupational Safety and Health. (1999a). Stress...at work (Publication No. 99-101). Retrieved from https://www.cdc.gov/niosh/docs/99-101/

National Institute for Occupational Safety and Health. (1999b). Strategies for preventing job stress suggested by CDC in new publication (Update). Retrieved from http://www.cdc.gov/niosh/updates/stresrel.html

Paloutzian, R. F., Emmons, R. A., \& Keortge, S. G. (2010). Spiritual well-being, spiritual intelligence, and healthy workplace policy. In R. A. Giacalone \& C. L. Jurkiewicz (Eds.), Handbook of workplace spirituality and organizational performance (2nd ed., pp. 73-86). New York, NY: M.E. Sharpe.

Park, C. L. (2012). Religious and spiritual aspects of meaning in the context of work life. In P. C. Hill \& B. J. Dik (Eds.), Psychology of religion and workplace spirituality. (pp. 2542). Charlotte, NC: Information Age Publishing.

Perry, J. C., Sigal, J. J., Boucher, S., \& Paré, N. (2006). Seven institutionalized children and their adaptation in late adulthood: The children of Duplessis (Les enfants de Duplessis). Psychiatry: Interpersonal and Biological Processes, 69, 283-301. doi:10.1521/psyc.2006.69.4.283

Pretorius, C. A. (2013). Caregivers' experiences of stress while caring for orphaned and vulnerable children in an institution (Master's thesis). University of Pretoria, Pretoria, South Africa. 
Richter, L. (2004). The importance of caregiver-child interactions for the survival and healthy development of young children: A review. Geneva, Switzerland: Department of Child and Adolescent Health and Development, World Health Organization. Retrieved from

http://www.google.no/url?sa=t\&rct=j\&q=\&esrc=s\&source=web\&cd=1\&ved=0ahUKEw j698i_8qHWAhXFORoKHVeTCA4QFggmMAA\&url=http\%3A\%2F\%2Fwhqlibdoc.w ho.int\%2Fpublications\%2F2004\%2F924159134X.pdf\&usg=AFQjCNHjkgxygDnKdm3 Qa2FrwTLSCm6Aww

Rosso, B. D., Dekas, K. H., \& Wrzesniewski, A. (2010). On the meaning of work: A theoretical integration and review. Research in Organizational Behavior, 30, 91-127. doi:10.1016/j.riob.2010.09.001

Rothmann, S., \& Buys, C. (2011). Job demands and resources, psychological conditions, religious coping and work engagement of reformed church ministers. Journal of Psychology in Africa, 21(2), 173-184.

Saks, A. M. (2011). Workplace spirituality and employee engagement. Journal of Management, Spirituality \& Religion, 8(4), 317-340. $\underline{\text { doi:10.1080/14766086.2011.630170 }}$

Schaufeli, W. B., \& Bakker, A. B. (2004). Job demands, job resources, and their relationship with burnout and engagement: A multisample study. Journal of Organizational Behavior, 25(3), 293-315. doi:10.1002/job.248

Schaufeli, W. B., \& Taris, T. W. (2014). A critical review of the job demands-resources model: Implications for improving work and health. In G. F. Bauer \& O. Hämmig (Eds.), Bridging Occupational, Organizational and Public Health (pp. 43-68). Amsterdam, The Netherlands: Springer. doi:10.1007/978-94-007-5640-3_4

Sekhar, C., Patwardhan, M., \& Singh, R. K. (2013). A literature review on motivation. Global Business Perspectives, 1, 471-487. doi:10.1007/s40196-013-0028-1

SOS Children's Villages International. (2010). Guidelines for the alternative care of children: A United Nations framework (General Assembly A/RES/64/142). Innsbruck, Austria: SOS Children's Villages International, Programme Development. Retrieved from http://www.sos-childrensvillages.org/getmedia/301cf6f5-0a8c-430f-9fadac99068ebd23/101203-UN-Guidelines-en-WEB.pdf?ext=.pdf

Spector, P. E., Fox, S., \& Domagalski, T. (2006). Emotions, violence and counterproductive work behavior. In E. K. Kelloway, J. Barling, \& J. J. Hurrell, Jr. (Eds.), Handbook of workplace violence (Ch. 3). Thousand Oaks, CA: Sage.

The St. Petersburg-USA Orphanage Research Team. (2008). The effects of early socialemotional and relationship experience on the development of young orphanage children. Monographs of the Society for Research in Child Development, 73(3), vii-295. doi:10.1111/j.1540-5834.2008.00483.x 
Torkelson, E., Holm, K., Bäckström, M., \& Schad, E. (2016). Factors contributing to the perpetration of workplace incivility: The importance of organizational aspects and experiencing incivility from others. Work \& Stress, 30(2), 115-131.

doi:10.1080/02678373.2016.1175524

Trout, A. L., Hagaman, J., Casey, K., Reid, R., \& Epstein, M. H. (2008). The academic status of children and youth in out-of-home care: A review of the literature. Children and Youth Services Review, 30(9), 979-994. doi:10.1016/j.childyouth.2007.11.019

Wieclaw, J., Agerbo, E., Mortensen, P. B., \& Bonde, J. P. (2006). Risk of affective and stress related disorders among employees in human service professions. Occupational and Environmental Medicine, 63, 314-319. doi:10.1136/oem.2004.019398

Yendork, J. S., \& Somhlaba, N. Z. (2015). Do social support, self-efficacy and resilience influence the experience of stress in Ghanaian orphans? An exploratory study. Child Care in Practice, 21(2), 140-159. doi:10.1080/13575279.2014.985286 